\title{
Prevalence of diabetes mellitus and impaired glucose tolerance in parents of women with gestational diabetes
}

\author{
J. A.S. McLellan ${ }^{1}$, B. A.Barrow ${ }^{1}$, J. C.Levy ${ }^{1}$, M.S.Hammersley ${ }^{1}$, A. T. Hattersley ${ }^{1}$, M. D. G. Gillmer ${ }^{2}$, R. C. Turner ${ }^{1}$ \\ ${ }^{1}$ Diabetes Research Laboratories, Radcliffe Infirmary, Oxford, UK \\ ${ }^{2}$ Department of Obstetrics, John Radcliffe Hospital, Oxford, UK
}

Summary Nuclear families of non-insulin-dependent diabetic (NIDDM) patients are uncommon, as usually one or both parents have died. In order to aid identification of complete nuclear families, we have ascertained the disease process at a younger age by studying subjects with previous gestational diabetes. One hundred women who had had gestational diabetes, age ( \pm SD) 38 (6) years, were screened by fasting plasma glucose (fpg). Sixty-one were found to have either fasting hyperglycaemia $(5.5 \leq \mathrm{fpg}<7.8 \mathrm{mmol} / \mathrm{l})$ or diabetes. Of these women 35 had both parents alive and the parents of 14 of these women agreed to the assessment of their metabolism by a continuous infusion of glucose with model assessment (CIGMA). Seven probands had impaired glucose tolerance (IGT) and seven were diabetic. They were age 35 (4) years and had body mass index (BMI) $26(5) \mathrm{kg} / \mathrm{m}^{2}$. The parents were aged 62 (6) years and had BMI 29 (6) $\mathrm{kg} / \mathrm{m}^{2}$ and their affection status was defined as presence of glucose intolerance (fpg or post-infusion achieved plasma glucose level $>2$ SD of an age and obesity matched population). In the 14 families, five probands $(36 \%)$ had neither parent affected, six $(43 \%)$ had one parent affected and three $(21 \%)$ had both parents affected. Only three probands had a parent with diabetes as defined by World Health Organisation criteria. We concludes that the study of women who have had gestational diabetes allows detection of probands with diabetes or impaired glucose tolerance, who have both parents available for study. A substantial proportion had neither parent affected with impaired glucose tolerance or diabetes, similar to the nuclear families of NIDDM patients. The results are in accord with studies of nuclear families of NIDDM patients in suggesting polygenic inheritance or environmental influences rather than autosomal dominant inheritance with high penetrance. [Diabetologia (1995) 38: 693-698]

Key words Inheritance diabetes, beta cell function, gestational diabetes, non-insulin-dependent diabetes, impaired glucose tolerance.
Women who have gestational diabetes have an increased risk of developing non-insulin-dependent diabetes mellitus (NIDDM) later in life. Within

Received: 6 June 1994 and in revised form: 13 December 1994

Corresponding author: Dr. R. C. Turner, Diabetes Research Laboratories, Radcliffe Infirmary, Woodstock Road, Oxford $\mathrm{OX} 26 \mathrm{HE}$, UK

Abbreviations: IGT, Impaired glucose tolerance; GTT, glucose tolerance test; NIDDM, non-insulin-dependent diabetes mellitus; fpg, fasting plasma glucose; apg, achieved plasma glucose; CIGMA, continuous infusion of glucose test; BMI, body mass index.
25 years, more than $50 \%$ of the women develop diabetes [1]. Approximately $30 \%$ of women who present with NIDDM in middle age have previously been suspected to have diabetes in pregnancy because of hyperglycaemia or glycosuria [2]. Women who have had gestational diabetes present an opportunity to study diabetes at an early stage in its evolution [3]. They are often overweight, and have both impaired beta-cell function and increased insulin resistance $[4,5]$. These are similar defects to those found in the first degree relatives of NIDDM patients [5-7].

Studies of inheritance of NIDDM have been restricted because of the difficulty in identifying two 
Table 1. The clinical characteristics of the probands who had had gestational diabetes and on testing had either fasting hyperglycaemia or diabetes (fasting plasma glucose $\geq 7.8 \mathrm{mmol} / \mathrm{l}$ )

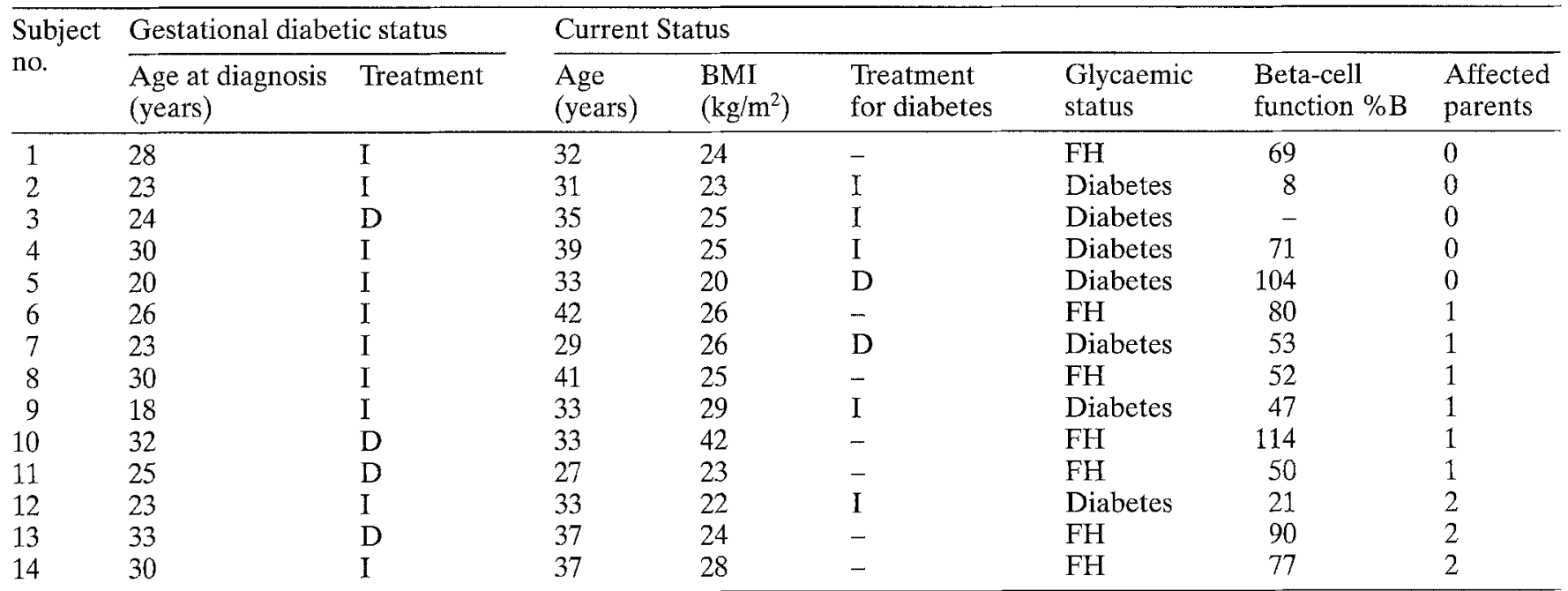

Beta-cell function was assessed by HOMA from fpg and C-peptide concentrations. The last column shows the number of parents of each proband who, in the study, were found to have either fasting hyperglycaemia or diabetes. I, Insulin; D, diet

generation, nuclear families in which both parents of a diabetic patient are alive and available for study [8]. Cook et al. [9] recently identified 20 NIDDM patients with nuclear families to ascertain the distribution of NIDDM in the parents, and the apparent pattern of inheritance [9]. A parent was diabetic in only seven pedigrees, and in an additional six pedigrees a parent had glucose intolerance. One-third of the diabetic patients had neither parent affected, raising the possibilities that either a substantial proportion of diabetes is environmental in origin or that the disease is polygenic, with diabetic determinants being inherited from both parents who may themselves not necessarily be diabetic. Since the diabetic patients were a mean age at diagnosis of 40 years and their parents were in their $7^{\text {th }}$ to $10^{\text {th }}$ decades, an inevitable potential bias was present since the need to have both parents alive would have excluded probands whose parents were diabetic and had died prematurely from disease-related increased mortality.

We have studied the parents of women who had had gestational diabetes, and who, on retesting, had either mild diabetes or impaired glucose tolerance and were therefore likely to develop diabetes. By identifying these patients at an early stage in the evolution of diabetes, their parents may be younger and it is more likely that both will be alive and available for studies to determine the pattern of inheritance of diabetes. In addition, those families in which one parent is diabetic and the other normoglycaemic, would be suitable for linkage studies to assess the potential role of candidate genes in NIDDM with one or more affected offspring.

\section{Subjects and methods}

The Central Oxford Research and Ethics Committee approved the protocol, and all subjects gave their informed consent.

One hundred white Caucasian subjects were studied who had developed gestational diabetes and still lived in the $\mathrm{Ox}$ ford area (Table 1). They were ascertained from registers of women who had had diabetes in pregnancy without regard to the family history of diabetes. They were mean age 38 (SD6) years old and were studied mean (SD) 11 (6) years after the pregnancy in which gestational diabetes had been diagnosed, 55 in their first pregnancy, 25 in the second, 20 in the third or subsequent pregnancies. Gestational diabetes had been diagnosed when two or more venous plasma glucose concentrations were equal to or exceeded the normal upper limits either fasting or following a 75-g oral glucose tolerance test (GTT) at 28-34 weeks' gestation, the upper limits of normal values at 0 , 1,2 and $3 \mathrm{~h}$ were taken as $<5.8,<12.5,<9.5,<7.5 \mathrm{mmol} / \mathrm{l}$ [10]. Forty-eight patients had been treated with insulin during pregnancy.

The subjects had their obesity assessed as body mass index (BMI) and their fasting plasma glucose (fpg) estimated by the mean of three 5-min venous blood samples. Subjects with fasting hyperglycaemia (fpg $\geq 5.5 \mathrm{mmol} / \mathrm{l}$ i.e., $>95^{\text {th }}$ percentile of a normal population), were selected for further study if both their parents were alive. Thus, each proband had both had gestational diabetes and subsequently had fasting hyperglycaemia. Beta-cell function was assessed from fasting glucose and C-peptide concentrations using HOMA model assessment [11] in all patients, including those on insulin therapy. This evaluates the patient's glucose and C-peptide concentrations in a mathematical model of the body's glucose and insulin interactions, in which equimolar production of insulin and $\mathrm{C}$-peptide is assumed. The model assesses the degree of insulin resistance and beta-cell impairment that would be expected to produce the patient's fasting glucose and C-peptide concentrations. As plasma C-peptide rather than insulin was assessed, beta-cell function could be evaluated even in those on insulin therapy.

Parents of probands willing to undergo studies were studied with a continuous infusion of glucose (CIGMA) test [12]. This 
Table 2. The clinical characteristics of parents of five gestational diabetic subjects with unaffected parents

\begin{tabular}{|c|c|c|c|c|c|c|c|c|c|}
\hline $\begin{array}{l}\text { Subject } \\
\text { no. }\end{array}$ & $\begin{array}{l}\text { Parent's } \\
\text { gender }\end{array}$ & $\begin{array}{l}\text { Age } \\
\text { (years) }\end{array}$ & $\begin{array}{l}\mathrm{BMI} \\
\left(\mathrm{kg} / \mathrm{m}^{2}\right)\end{array}$ & $\begin{array}{l}\text { Fasting plasma } \\
\text { glucose } \\
(\mathrm{mmol} / 1)\end{array}$ & $\begin{array}{l}\text { Achieved plasma } \\
\text { glucose } \\
(\mathrm{mmol} / \mathrm{l})\end{array}$ & $\begin{array}{l}\mathrm{HbA}_{1 \mathrm{c}} \\
(\%)\end{array}$ & $\begin{array}{l}\text { fpg Z } \\
\text { (SD) }\end{array}$ & $\begin{array}{l}\operatorname{apg} Z \\
\text { (SD) }\end{array}$ & $\begin{array}{l}\text { Glycaemic } \\
\text { status }\end{array}$ \\
\hline 1 & $\begin{array}{l}\text { Male } \\
\text { Female }\end{array}$ & $\begin{array}{l}61 \\
60\end{array}$ & $\begin{array}{l}30 \\
22\end{array}$ & $\begin{array}{l}5.0 \\
4.8\end{array}$ & $\begin{array}{l}8.8 \\
7.4\end{array}$ & $\begin{array}{l}5.7 \\
5.4\end{array}$ & $\begin{array}{l}0.5 \\
0.05\end{array}$ & $\begin{array}{r}0.5 \\
-1.5\end{array}$ & $\begin{array}{l}\text { Normal } \\
\text { Normal }\end{array}$ \\
\hline 2 & $\begin{array}{l}\text { Male } \\
\text { Female }\end{array}$ & $\begin{array}{l}58 \\
59\end{array}$ & $\begin{array}{l}25 \\
24\end{array}$ & $\begin{array}{l}5.0 \\
5.0\end{array}$ & $\begin{array}{l}7.8 \\
7.9\end{array}$ & $\begin{array}{l}5.4 \\
5.6\end{array}$ & $\begin{array}{l}0.5 \\
0.5\end{array}$ & $\begin{array}{l}-0.8 \\
-0.8\end{array}$ & $\begin{array}{l}\text { Normal } \\
\text { Normal }\end{array}$ \\
\hline 3 & $\begin{array}{l}\text { Male } \\
\text { Female }\end{array}$ & $\begin{array}{l}63 \\
55\end{array}$ & $\begin{array}{l}24 \\
50\end{array}$ & $\begin{array}{l}5.3 \\
4.6\end{array}$ & $\begin{array}{l}9.6 \\
6.9\end{array}$ & $\begin{array}{l}5.7 \\
5.2\end{array}$ & $\begin{array}{r}1.1 \\
-0.3\end{array}$ & $\begin{array}{l}0.9 \\
0.01\end{array}$ & $\begin{array}{l}\text { Normal } \\
\text { Normal }\end{array}$ \\
\hline 4 & $\begin{array}{l}\text { Male } \\
\text { Female }\end{array}$ & $\begin{array}{l}65 \\
64\end{array}$ & $\begin{array}{l}26 \\
25\end{array}$ & $\begin{array}{l}5.4 \\
4.9\end{array}$ & $\begin{array}{l}8.7 \\
8.0\end{array}$ & $\begin{array}{l}6.7 \\
5.2\end{array}$ & $\begin{array}{l}1.2 \\
0.2\end{array}$ & $\begin{array}{c}0.01 \\
-0.7\end{array}$ & $\begin{array}{l}\text { Normal } \\
\text { Normal }\end{array}$ \\
\hline 5 & $\begin{array}{l}\text { Male } \\
\text { Female }\end{array}$ & $\begin{array}{l}53 \\
49\end{array}$ & $\begin{array}{l}32 \\
24\end{array}$ & $\begin{array}{l}4.8 \\
5.0\end{array}$ & $\overline{9.5}$ & $\begin{array}{l}5.7 \\
5.7\end{array}$ & $\begin{array}{l}0.2 \\
0.8\end{array}$ & $\overline{1.1}$ & $\begin{array}{l}\text { Normal } \\
\text { Normal }\end{array}$ \\
\hline \multicolumn{2}{|c|}{ Mean (1 SD) } & $59(5)$ & $28(8)$ & $5.0(0.2)$ & & $5.6(0.4)$ & & & \\
\hline
\end{tabular}

The fpg and apg concentrations after the 1-h CIGMA test (apg) are shown as Z scores, the deviation in SD from the mean of an age and BMI-matched normal population

Table 3. The clinical characteristics of the parents of a gestational diabetic subjects with one or both parents affected

\begin{tabular}{|c|c|c|c|c|c|c|c|c|c|c|c|}
\hline $\begin{array}{l}\text { Subject } \\
\text { no. }\end{array}$ & $\begin{array}{l}\text { Parent's } \\
\text { Sex }\end{array}$ & $\begin{array}{l}\text { Age } \\
\text { (years) }\end{array}$ & $\begin{array}{l}\text { BMI } \\
\left(\mathrm{kg} / \mathrm{m}^{2}\right)\end{array}$ & $\begin{array}{l}\text { Fasting } \\
\text { plasma } \\
\text { glucose } \\
(\mathrm{mmol} / \mathrm{l}) \\
\end{array}$ & $\begin{array}{l}\text { Achieved } \\
\text { plasma } \\
\text { glucose } \\
(\mathrm{mmol} / \mathrm{l}) \\
\end{array}$ & $\begin{array}{l}\mathrm{HbA}_{1 \mathrm{c}} \\
(\%)\end{array}$ & $\begin{array}{l}\text { fpg Z } \\
\text { (SD) }\end{array}$ & $\begin{array}{l}\operatorname{apg} Z \\
\text { (SD) }\end{array}$ & $\begin{array}{l}\text { Glycaemic } \\
\text { status }\end{array}$ & $\begin{array}{l}\text { Duration } \\
\text { of known } \\
\text { diabetes } \\
\text { (years) }\end{array}$ & $\begin{array}{l}\text { Current } \\
\text { treat- } \\
\text { ment }\end{array}$ \\
\hline 6 & $\begin{array}{l}\text { Male } \\
\text { Female }\end{array}$ & $\begin{array}{l}74 \\
67\end{array}$ & $\begin{array}{l}30 \\
29\end{array}$ & $\begin{array}{l}6.0 \\
5.5\end{array}$ & $\begin{array}{l}9.2 \\
9.5\end{array}$ & $\begin{array}{l}6.3 \\
6.2\end{array}$ & $\begin{array}{l}2.3 \\
1.4\end{array}$ & $\begin{array}{l}0.6 \\
1.0\end{array}$ & $\begin{array}{l}\text { IGT } \\
\text { Normal }\end{array}$ & - & $\begin{array}{l}- \\
-\end{array}$ \\
\hline 7 & $\begin{array}{l}\text { Male } \\
\text { Female }\end{array}$ & $\begin{array}{l}55 \\
50\end{array}$ & $\begin{array}{l}33 \\
21\end{array}$ & $\begin{array}{l}5.6 \\
5.0\end{array}$ & $\begin{array}{r}10.0 \\
9.5\end{array}$ & $\begin{array}{l}5.8 \\
5.7\end{array}$ & $\begin{array}{l}1.9 \\
0.7\end{array}$ & $\begin{array}{l}2.0 \\
0.9\end{array}$ & $\begin{array}{l}\text { IGT } \\
\text { Normal }\end{array}$ & - & - \\
\hline 8 & $\begin{array}{l}\text { Male } \\
\text { Female }\end{array}$ & $\begin{array}{l}69 \\
68\end{array}$ & $\begin{array}{l}30 \\
31\end{array}$ & $\begin{array}{r}10.3 \\
5.7\end{array}$ & $\overline{9.4}$ & $\begin{array}{l}8.2 \\
5.4\end{array}$ & $\begin{array}{r}11.9 \\
1.8\end{array}$ & $\overline{-}$ & $\begin{array}{l}\text { Diabetes } \\
\text { Normal }\end{array}$ & $\begin{array}{l}12 \\
-\end{array}$ & $\begin{array}{l}I \\
-\end{array}$ \\
\hline 9 & $\begin{array}{l}\text { Male } \\
\text { Female }\end{array}$ & $\begin{array}{l}62 \\
68\end{array}$ & $\begin{array}{l}26 \\
27\end{array}$ & $\begin{array}{l}5.0 \\
6.1\end{array}$ & $\begin{array}{r}8.9 \\
10.3\end{array}$ & $\begin{array}{l}5.2 \\
6.3\end{array}$ & $\begin{array}{l}0.4 \\
2.7\end{array}$ & $\begin{array}{l}0.3 \\
1.7\end{array}$ & $\begin{array}{l}\text { Normal } \\
\text { IGT }\end{array}$ & - & - \\
\hline 10 & $\begin{array}{l}\text { Male } \\
\text { Female }\end{array}$ & $\begin{array}{l}68 \\
59\end{array}$ & $\begin{array}{l}32 \\
28\end{array}$ & $\begin{array}{l}5.1 \\
5.9\end{array}$ & $\begin{array}{r}9.0 \\
10.7\end{array}$ & $\begin{array}{l}6.2 \\
5.8\end{array}$ & $\begin{array}{l}0.5 \\
2.5\end{array}$ & $\begin{array}{l}0.6 \\
2.4\end{array}$ & $\begin{array}{l}\text { Normal } \\
\text { IGT }\end{array}$ & - & $\begin{array}{l}- \\
-\end{array}$ \\
\hline 11 & $\begin{array}{l}\text { Male } \\
\text { Female }\end{array}$ & $\begin{array}{l}49 \\
47\end{array}$ & $\begin{array}{l}28 \\
23\end{array}$ & $\begin{array}{l}7.4 \\
4.3\end{array}$ & - & $\begin{array}{l}7.4 \\
5.1\end{array}$ & $\begin{array}{r}6.1 \\
-0.7\end{array}$ & $\begin{array}{l}- \\
-\end{array}$ & $\begin{array}{l}\text { IGT } \\
\text { Normal }\end{array}$ & $\begin{array}{l}- \\
-\end{array}$ & - \\
\hline 12 & $\begin{array}{l}\text { Male } \\
\text { Female }\end{array}$ & $\begin{array}{l}66 \\
61\end{array}$ & $\begin{array}{l}29 \\
35\end{array}$ & $\begin{array}{r}9.3 \\
18.2\end{array}$ & $\begin{array}{c}15.0 \\
-\end{array}$ & $\begin{array}{r}6.8 \\
10.8\end{array}$ & $\begin{array}{l}9.8 \\
30\end{array}$ & $\begin{array}{l}6.7 \\
-\end{array}$ & $\begin{array}{l}\text { Diabetes } \\
\text { Diabetes }\end{array}$ & $\begin{array}{r}0 \\
12\end{array}$ & $\overline{\mathrm{I}}$ \\
\hline 13 & $\begin{array}{l}\text { Male } \\
\text { Female }\end{array}$ & $\begin{array}{l}66 \\
67\end{array}$ & $\begin{array}{l}29 \\
29\end{array}$ & $\begin{array}{l}6.3 \\
6.0\end{array}$ & $\begin{array}{r}10.5 \\
9.7\end{array}$ & $\begin{array}{l}5.8 \\
5.7\end{array}$ & $\begin{array}{l}3.2 \\
2.5\end{array}$ & $\begin{array}{l}2.0 \\
1.2\end{array}$ & $\begin{array}{l}\text { IGT } \\
\text { IGT }\end{array}$ & - & $\begin{array}{l}- \\
-\end{array}$ \\
\hline 14 & $\begin{array}{l}\text { Male } \\
\text { Female }\end{array}$ & $\begin{array}{l}71 \\
67\end{array}$ & $\begin{array}{l}31 \\
27\end{array}$ & $\begin{array}{l}6.6 \\
5.7\end{array}$ & $\begin{array}{c}10.3 \\
-\end{array}$ & $\begin{array}{l}5.7 \\
7.9\end{array}$ & $\begin{array}{l}3.7 \\
1.8\end{array}$ & $\begin{array}{l}1.8 \\
-\end{array}$ & $\begin{array}{l}\text { IGT } \\
\text { Diabetes }\end{array}$ & $\overline{5}$ & $\overline{\mathrm{I}}$ \\
\hline \multicolumn{2}{|c|}{ Mean (1 SD) } & $63(8)$ & $29(3)$ & $6.9(3.2)$ & & $6.5(1$. & & & & & \\
\hline
\end{tabular}

Fasting plasma glucose (fpg) and achieved plasma glucose (apg) are shown as Z scores, the deviation in SD from the mean of an age- and BMI-matched normal population

consisted of a continuous intravenous infusion of $5 \mathrm{mg}$ giucose $\cdot \mathrm{kg}$ ideal body weight ${ }^{-1} \cdot \mathrm{min}^{-1}$ for $60 \mathrm{~min}$. The ideal body weight was taken from the Metropolitan Life Insurance tables for a medium frame [13]. Samples were taken from an intravenous cannula inserted at the wrist or back of the hand, which had been heated to arterialise the blood sample. Three fasting samples were taken at 5-min intervals and their mean glucose concentration was termed the fasting plasma glucose (fpg). The mean plasma glucose result in samples taken at 50-, 55-, and 60-min samples was termed the achieved plasma glucose (apg). A formal study of the reproducibility of the CIGMA test in 30 subjects (13 non-diabetic subjects, 11 diet-treated NIDDM patients, and 6 subjects with IGT) gave a coeffi- cient of variation of $5 \%$ [14]. Impaired glucose tolerance (IGT) was defined as a fpg or apg level 2 SD above the mean normal value for the subject's age and obesity, as determined in comparison with a population of 104 normal subjects (age range $21-76$ years, ideal body weight range $86-158 \%$ ). In Tables 2 and 3, the fpg and apg are expressed as a $Z$ score, in terms of SD from the mean of the age and BMI matched population. NIDDM was diagnosed according to the WHO criterion of fpg $>7.8 \mathrm{mmol} / 1$ [15]. Affection status was defined as including both IGT and NIDDM.

In seven elderly parents glucose tolerance testing was not performed. Three had known diabetes treated with insulin, and fasting plasma glucose and $\mathrm{HbA}_{1 \mathrm{c}}$ were obtained. In addi- 
tion, four non-diabetic patients who had chronic disease declined a CIGMA and were assessed with an fpg and $\mathrm{HbA}_{1 .}$, and were considered as affected if the fpg was greater than 2 SD above the mean normal value for the subject's age and level of obesity.

Plasma glucose was measured with a hexokinase method using a Cobas MIRA centrifugal analyser. $\mathrm{HbA}_{1 \mathrm{c}}$ was measured with ion-exchange high-performance liquid chromatography using the Bio-Rad DIAMAT (Richmond, Calif., USA). The normal range ( $\pm 2 \mathrm{SD})$ in a population of non-diabetic subjects aged $73 \pm 6$ years was $4.8-6.8 \%$.

Except where otherwise stated, the data are presented as means $\pm \mathrm{SD}$. Comparisons between groups were made with the Mann-Whitney U test.

\section{Results}

One hundred unrelated patients who had had gestational diabetes diagnosed for the first time in pregnancy were questioned. Sixty-one had either fasting hyperglycaemia (fpg $\geq 5.5$ to $<7.8 \mathrm{mmol} / \mathrm{l}$ ), previously undiagnosed diabetes (fpg $>7.8 \mathrm{mmol} / \mathrm{l}$ ) or known diabetes. In the case of 44 patients, one or both parents had died. A similar proportion with and without fasting hyperglycaemia, 26 of $61(43 \%)$ and 18 of $39(46 \%)$, respectively, had one or both parents dead. Only 35 had both parents alive and an fpg $\geq 5.5 \mathrm{mmol} / \mathrm{l}$. Of these, $14 \mathrm{had}$ both parents available and willing to be studied. During the pregnancy in which gestational diabetes was diagnosed, ten of the probands were treated with insulin and four were treated with diet alone. At the time of recruitment seven probands had known diabetes of whom five were on insulin treatment, six had impaired glucose tolerance on CIGMA testing and one proband (BMI $42 \mathrm{~kg} \cdot \mathrm{m}^{-2}$ ) had an fpg of $6.4 \mathrm{mmol} / \mathrm{I}$ (4.1 SD above normal fasting glucose for age and BMI), but a normal CIGMA achieved plasma glucose. Table 1 shows the clinical characteristics of the probands. Their beta-cell function was (geometric mean and 1 SD range) 54 (27-108) \%.

Of the parents of the 14 probands, 4 had known diabetes of whom 3 were being treated with insulin. Of the 24 parents without known diabetes, 21 were willing to undergo the glucose infusion test. In the 3 subjects who were not, affection status was assessed with a fasting plasma glucose. Five ( $36 \%$ ) probands had neither parent affected with NIDDM or IGT, $6(43 \%)$ had one parent affected (1 NIDDM 5 IGT) and $3(21 \%)$ had both parents affected (1 IGT/ IGT, 1 IGT/diabetes, 1 diabetes/diabetes). The proband with one or more affected parents and those with unaffected parents had similar age at diagnosis of gestational diabetes $(27 \pm 5$ and $25 \pm 4$ years and BMI $\left(28 \pm 6\right.$ and $\left.23 \pm 2 \mathrm{~kg} / \mathrm{m}^{2}\right)$.

The affected and unaffected parents were of similar age $(65 \pm 6,58 \pm 5$ years) and obesity $(29 \pm 3$, $\left.28 \pm 8 \mathrm{~kg} / \mathrm{m}^{2}\right)$. Tables 2 and 3 show the clinical details of the parents.
Neither parent affected

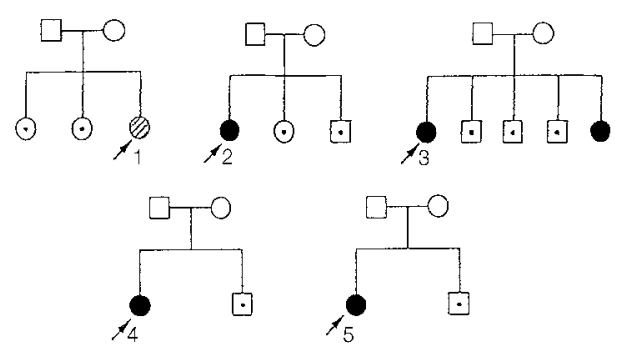

One parent affected

Glucose intolerant parent
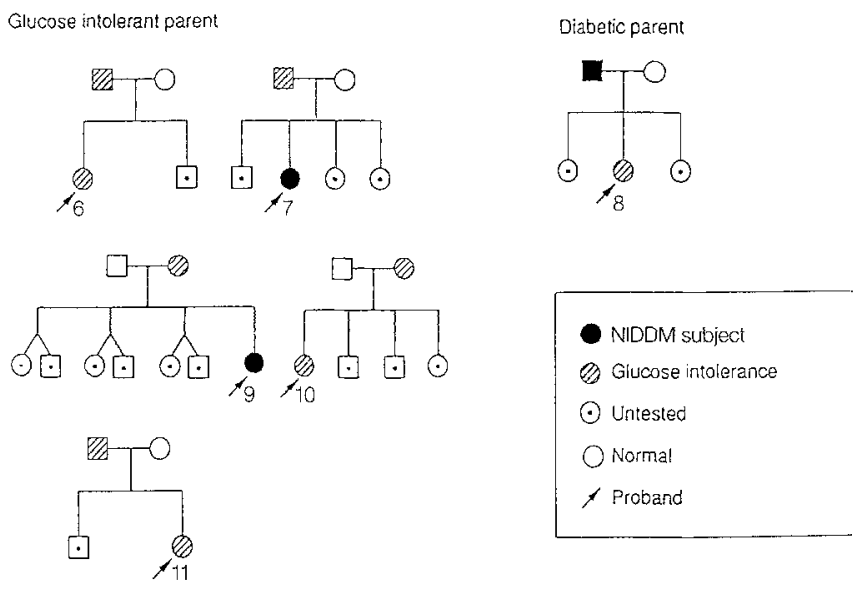

Both parents affected
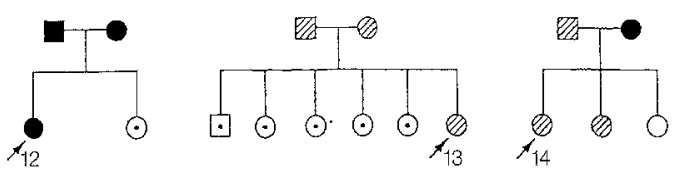

Fig. 1. The pedigrees of the 14 families who were studied. $\square=$ male, $O=$ female, open symbol normoglycaemia, hatched symbol fasting hyperglycaemia, closed symbol diabetes. Numbers correspond to the probands in Tables 1,2 and 3

The family trees are shown in Figure 1. In three of the five pedigrees in which one parent was affected, the affected parent was the father.

\section{Discussion}

The identification of two generation nuclear families suitable for genetic study via probands with NIDDM is hampered by a low yield. In a study of the ascertainment of suitable pedigrees from 950 known diabetic patients in Oxfordshire, only $127(13 \%)$ families were available for study [8]. The strategy investigated in this study was based on the identification of probands with a history of gestational diabetes who, on retesting, had evidence of IGT or NIDDM, with subsequent testing of their parents. This strategy has the potential advantage of the identification of NIDDM at an early stage of development, and increases the possibility of both the parents of the proband being alive. Most potential probands had developed gesta- 
tional diabetes in their first or second pregnancy, and were studied at a mean age of 38 years, 10 years after the initial diagnosis of gestational diabetes. At this time, $61 \%$ had either developed diabetes or had IGT and were therefore at high risk of developing diabetes, in accord with previously described data. However, only a little over half the patients had both parents alive, with a final yield of potential probands of $35 \%$. If the characterisation of the families of gestational diabetic patients had occurred nearer the time of the original diagnosis the proportion with living parents might have been increased. On the other hand, it is likely that the number of probands with fasting hyperglycaemia would be reduced. Of the 35 potential probands, $40 \%$ of patients and parents were available and willing to be studied as a family, representing $23 \%$ of those with fasting hyperglycaemia. This is a larger yield than that from known diabetic patients in the Oxfordshire study [8], and provides a complementary strategy for the collection of pedigree data suitable for genetic studies. As one might expect that those with a diabetic parent would be more likely to volunteer for the study, this would counteract any potential bias from not being able to study families in which a parent had died from a diabetes-related cause. In any case, such a supposition seems unlikely, as there was no difference in the proportion of subjects in whom one or both parents had died between those who were now normoglycaemic or who had fasting hyperglycaemia.

The pattern of affection in parents of the gestational diabetic probands is similar to that found in the parents of NIDDM patients in whom a sizeable proportion ( 7 of 20) were found to have neither parent affected with diabetes or IGT [9]. That study indicated that the assumption of autosomal dominant inheritance with complete penetrance was not applicable and the current study would be consistent with this. The low prevalence of affection in the parents at age 60 years is in keeping with polygenic inheritance or environmental factors inducing the diabetes [9]. Even when one parent was affected, we found in four of the five sets of parents that IGT rather than diabetes was present. These data are therefore consistent with families of NIDDM parents, and are in keeping with polygenic inheritance and/or environmental influences. Three of the probands had two parents affected. This is a similar proportion to the 3 of 20 NIDDM patients who had both affected parents. This is a higher incidence than would be expected by chance with a dominant model. Some of the patients who present with gestational diabetes in their 20 's have similarities with those who present with early onset diabetes in their late 30's, and it is possible that both affected parents may have given a "double gene dose" that induced early presentation [16].

The gestational diabetic probands had impaired beta-cell function, comparable to that found in first de- gree relatives of NIDDM patients with similar fasting hyperglycaemia [7]. It is likely that the insulin resistance associated with pregnancy and the accompanying screening for hyperglycaemia allowed early detection of the development of diabetes and that their pathophysiology is the same as that in classic NIDDM. This is not surprising since $30 \%$ of females who present with diabetes at mean age 52 years have previously undergone pregnancy with suspected diabetes [2].

Acknowledgements. The Alan and Babette Sainsbury Charitable Trust provided financial support for the study. Screening of patients with gestational diabetes was funded by a grant from Servier, as part of the Fasting Hyperglycaemia Study. Dr. A.T.Hattersley was an MRC Research Fellow. We thank the families for their collaboration, and Ms. N. Walravens who helped with the GTT's, Ms. M.Burnett, Ms. P.Sutton and D. Jelfs for technical assistance.

\section{References}

1. O'Sullivan JB (1975) Long term follow-up of gestational diabetes. In: Camerini Davalos RA, Cole HS (eds) Early diabetes. Academic Press, New York, pp 1009-1027

2. UK Prospective Diabetes Study (UKPDS Group) IV (1988) Characteristics of newly-presenting type 2 diabetic patients: male preponderance and obesity at different ages. Diabet Med 5: 154-159

3. Dornhorst A, Bignall PC, Anyaoku V, Elkeles RS, Johnston DG, Beard RW (1990) Abnormalities of glucose tolerance following gestational diabetes. QJ Med New Ser 284: 1219-1228

4. Ward WK, Johnstone CLW, Beard JC, Benedette TJ, Halter JB, Porte D (1985) Insulin resistance and impaired insulin secretion in subjects with histories of gestational diabetes mellitus. Diabetes 34: 861-869

5. Page RCL, Walravens EKN, Levy JC, Stratton IM, Turner RC (1993) Prevalence and pathophysiology of impaired glucose tolerance in three different high risk Caucasian. groups. Metabolism 4: 932-938

6. Eriksson J, Franssila-Kallunki A, Ekstrand A et al. (1989) Early metabolic defects in persons at increased risk for non-insulin-dependent diabetes mellitus. N Engl J Med 321: $337-343$

7. O'Rahilly SP, Rudenski AS, Burnett MA, Nugent Z, Hosker JP, Darling P, Turner RC (1986). Beta-cell dysfunction rather than insulin insensitivity is the primary defect in familial type 2 diabetes. Lancet I: 360-364

8. Cook JTE, Page RCL, O'Rahilly S et al. (1993) Availability of type II diabetic families for detection of diabetes susceptibility genes. Diabetes 42: 1536-1543

9. Cook JTE, Hattersley AT, Levy JC et al. (1993) Distribution of type II diabetes in nuclear families. Diabetes 42 : 106-112

10. Gillmer MDG, Oakley NW, Beard RW et al. (1980) Screening for diabetes during pregnancy. Br J Obstet Gynecol 87 : $377-387$

11. Matthews DR, Hosker JP, Rudenski AS, Naylor BA, Treacher DF, Turner RC (1985) Homeostasis model assessment: insulin resistance and $\mathrm{B}$-cell function from fasting plasma glucose and insulin concentrations in man. Diabetologia 28: 412-419

12. Hosker JP, Matthews DR, Rudenski A et al. (1985) Continuous infusion of glucose with model assessment: measure- 
ment of insulin resistance and $\beta$-cell function in man. Diabetologia 28: 401-411

13. Metropolitan Life Insurance Company (1959) New weight standard for men and women. Statistical Bulletin Metropolitan Life 40: 1-4

14. Hammersley MS, Levy JC, Volpicelli G, Barrow B, Turner RC (1992) Assessment of impaired glucose tolerance and beta-cell function with a continuous infusion of glucose test and an oral glucose tolerance test. Diabet Med 9 [Suppl 1]: P 17 (Abstract)

15. WHO Study Group (1985) Diabetes mellitus. World Health Organisation. Technical Report Series No 727. WHO Geneva

16. O’Rahilly SP, Spivey RS, Holman RR, Nugent Z, Clark A, Turner RC (1987) Type 2 diabetes of early onset: a distinct clinical and genetic syndrome. BMI 294: 923-928 